\title{
Detection of Vibrio cholerae in street food (satar and otak-otak) by Loop- Mediated Isothermal Amplification (LAMP), multiplex Polymerase Chain Reaction (mPCR) and plating methods
}

\author{
${ }^{1 *}$ Tang, J-Y-H., ${ }^{1}$ Farhana Sakinah, M.R., ${ }^{2}$ Nakaguchi, Y., ${ }^{3}$ Nishibuchi, M., ${ }^{4}$ Chai, L-C., \\ ${ }^{5}$ New, C.Y. and ${ }^{5,6}$ Son, R. \\ ${ }^{1}$ Faculty of Bioresources and Food Industry, Universiti Sultan Zainal Abidin, 22200 Besut, Terengganu \\ ${ }^{2}$ Center for Southeast Asian Studies, Kyoto University, Kyoto, Japan \\ ${ }^{3}$ Department of Food Science, Faculty of Bioresources and Environmental Sciences, Ishikawa Prefectural \\ University, 1-308, Suematsu, Nonoichi-shi, Ishikawa-ken, 921-8836 Japan \\ ${ }^{4}$ Institute of Biological Sciences, Faculty of Science, University of Malaya, 50603 Kuala Lumpur, Malaysia \\ ${ }^{5}$ Department of Food Science, Faculty of Food Science and Technology, Universiti Putra Malaysia, 43400 \\ UPM Serdang, Selangor, Malaysia \\ ${ }^{6}$ Food Safety and Food Integrity, Institute of Tropical Agriculture and Food Security, Universiti Putra \\ Malaysia, 43400 UPM Serdang, Selangor, Malaysia
}

\begin{abstract}
Article history: July 2018

2018

Keywords:

Vibrio cholerae,

LAMP,

Multiplex PCR,

Plating
\end{abstract}

Received: 28 May 2018

Received in revised form: 7

Accepted: 10 July 2018

Available Online: 19 July

DOI:

https://doi.org/10.26656/fr.2017.2(5).099

\begin{abstract}
This goal of this study was to investigate the presence of Vibrio cholerae in street food, namely satar and otak-otak, using Loop-Mediated Isothermal Amplification (LAMP), multiplex Polymerase Chain Reaction (mPCR) and conventional plating on Thiosulphate Citrate Bile-Salt Sucrose (TCBS) agar methods. A total of 78 satar and 35 otak-otak were purchased from different districts of Terengganu (Besut, Setiu, Kuala Terengganu and Kemaman). $V$. cholerae was found in satar with LAMP (10.3\%), mPCR (10.3\%) and plating $(0 \%)$. No $V$. cholerae was found in otak-otak using the three methods. This might be due to $V$. cholerae able to survive in satar after grilling due to its thickness which may contribute to undercooking. This study concluded that low presence of $V$. cholerae in satar and otak-otak can be detected by molecular methods but not the conventional plating method. LAMP assay is a useful tool for rapid detection of pathogens in food due to its simplicity, highly sensitive and visual interpretation capability. Though the prevalence of $V$. cholerae was low in the samples, proper handling of this food will help in reducing the risk of acquiring infection from $V$. cholerae in contaminated samples.
\end{abstract}

\section{Introduction}

Vibrio cholerae, a member of the family Vibrionaceae, is a facultatively anaerobic, Gramnegative, and non-spore-forming curved rod about 1.4-2.6 mm long (Baumann et al., 1984). V. cholerae live naturally in both marine and freshwater habitats and in association with aquatic animals (Feldhusen, 2000). The genus Vibrio of the family Vibrionaceae embraces more than 60 species, mostly marine in origin and its taxonomy is continuously being revised due to the addition of new species (Etinosa et al., 2008). The natural biota of fish might contain some Vibrio species (Colwell, 1996; Supungul et al., 2004).

Satar and otak-otak are popular street food in Terengganu that is usually consumed as snack or side dish. It is easy to find these foods in East Coast of
Peninsular Malaysia, namely Terengganu and Kelantan due to the abundance of fish in these states. Satar and otak-otak normally used round scad fish (selayang) or chub mackerel fish (kembung) as their main ingredient because these types of fish are cheaper than other fish. In Malaysia, satar and otak-otak are fish-based street food products that are usually prepared and grilled in a large amount before being served to customers. They are exposed to the ambient temperature for a long period of time which might cause multiplication of microorganism. The grilling process for satar and otakotak using charcoal require skills and doneness of the products are difficult to be determine. This is because if the grilling process is not handled carefully will result in the satar and otak-otak burnt on the outside but not cooked or undercooked inside. Thus, the microorganism or pathogen present in the sample will grow and cause 
foodborne illness.

Oliver (2003) reported that, foods implicated in the spread of Vibrio cholerae include seafood (raw fish, crabs, shrimp, mussels, cockles, squid, oysters, clams), rice, raw pork, street vendor food, frozen coconut milk, and raw fruits and vegetables, with greater survival occurring in cooked foods. $V$. cholerae is the etiological agent of cholera which is transmitted to human by ingestion of contaminated food or water, eating raw or improperly cooked seafood or seafood products, and also direct fecal contact with food handlers. $V$. cholerae serogroups $\mathrm{O} 1$ and $\mathrm{O} 139$ are usually found as the main causes of this disease (Kaper et al., 1995; Fraga et al., 2007; Suzita et al., 2009). This is due to more than $95 \%$ of these strains produce the cholera toxin (CT). The symptoms of cholera disease are characterized by abdominal cramps, nausea, vomiting, as well as massive acute diarrhoea. These symptoms cause the depletion of body fluids and electrolytes which are essential for life, causing dehydration to the infected person which might lead to death in severe and untreated cases (Rabbani and Greenough, 1999; Weinke et al. 2008; Shrestha et al., 2010). The aim of this paper is, therefore, to determine the presence of $V$. cholera in local popular street food, satar, and otak-otak, using novel molecular method LAMP, multiplex PCR and the conventional plating method.

\section{Materials and methods}

\subsection{Sample collection}
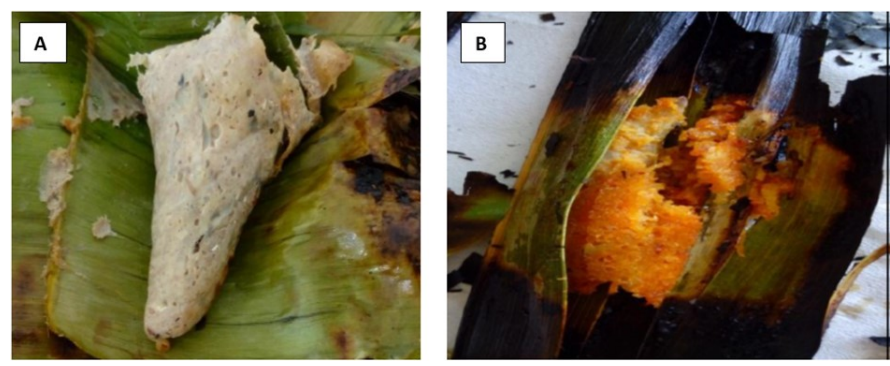

Figure 1. Fish-based product sold as street food. A) Satar and B) Otak-otak

Satar and otak-otak were chosen as popular fishbased street food products as shown in Figure 1. A total of 113 samples which consist of seventy-eight satar and thirty-five otak-otak were purchased from different stalls in districts of Terengganu such as Besut, Setiu, Kuala Terengganu, Marang and Kemaman. Each sample was labeled with an identification number to differentiate their place of origin.

\subsection{Enrichment of Vibrio cholerae in satar and otak-otak}

For enrichment method, $10 \mathrm{~g}$ of sample was weighed into a sterile stomacher bag and added with $90 \mathrm{~mL}$ of alkaline peptone water (APW) (Merck, Germany). The mixture was homogenized in the stomacher (Seward, UK) for $1 \mathrm{~min}$ at $250 \mathrm{rpm}$ and incubated at $37^{\circ} \mathrm{C}$ for 24 $\mathrm{h}$.

\subsection{Isolation of Vibrio cholerae from satar and otak-otak}

A loopful of the incubated samples was taken from the top pellicle and streaked onto duplicate selective medium TCBS agar plates (Merck, Germany). The agar plates were then incubated for $18-24 \mathrm{~h}$ at $37^{\circ} \mathrm{C}$. The presumptive colonies of $V$. cholerae (yellow colonies with 2-3 $\mathrm{mm}$ diameter) on TCBS agar plate were selected for further confirmation using PCR.

\subsection{DNA extraction}

$V$. cholerae DNA from vegetable samples will be extracted using boiled-cell method as described in Tang et al. (2014) with slight modification. A portion of 500 $\mu \mathrm{L}$ enriched sample was centrifuged at $10,000 \times \mathrm{g}$ to pellet the cells. The supernatant was discarded, and the pellet will be re-suspended with $500 \mu \mathrm{L}$ of sterile deionised water. The tube containing the re-suspended cells pellet was boiled at $100^{\circ} \mathrm{C}$ for 10 mins using digital dry bath (Corning, Japan). The boiled mixture was cooled at $-20^{\circ} \mathrm{C}$ for 10 mins before undergone centrifugation for 10 mins at $10,000 \times g$. The supernatant containing DNA was used for $V$. cholerae detection by multiplex PCR or LAMP.

\subsection{Molecular detection method}

\subsubsection{Multiplex PCR assay}

A multiplex PCR was used to detect the presence and virulence gene (hly $\mathrm{A}, t c p \mathrm{I}, c t x \mathrm{~B})$ of Vibrio cholerae in satar and otak-otak. Table 1 shows the sequence of specific primers used for detection of $V$. cholerae.

Table 1. Sequences of oligonucleotide primers used to target specific genes in Vibrio cholerae and their respective amplicons sizes.

\begin{tabular}{|c|c|c|c|c|}
\hline Target genes & Nucleotide sequences $5^{\prime}-3^{\prime}$ & $\operatorname{Tm}\left({ }^{\circ} \mathbf{C}\right)$ & $\begin{array}{c}\text { Amplicon size } \\
\text { (bp) }\end{array}$ & References \\
\hline $\operatorname{ctx} B-F$ & ATG AGG CGT TTT ATT CCA TAC AC & \multirow{2}{*}{57.5} & \multirow{2}{*}{128} & \multirow{2}{*}{ Imani et al. (2013) } \\
\hline $\operatorname{ctx} B-R$ & TAC CAG GTA GTC AAC ATA TAG ATT CA & & & \\
\hline tcpI-F & TGC GTG ATG CTA ATT GGA CT & \multirow{2}{*}{60.4} & \multirow{2}{*}{444} & \multirow{2}{*}{ Imani et al. (2013) } \\
\hline tcpI-R & TTC GGT TTG TTT GCT TGA TG & & & \\
\hline$h l y A-F$ & GGC AAA CAG CGA AAC AAA TAC C & \multirow{2}{*}{59.0} & \multirow{2}{*}{738} & \multirow{2}{*}{ Panicker et al. (2004) } \\
\hline$h l y A-R$ & CTC AGC GGG CTA ATA CGG TTT A & & & \\
\hline
\end{tabular}


Multiplex PCR was performed in a $25 \mathrm{uL}$ reaction mixture containing $12.1 \mu \mathrm{L}$ of sterile ultra-pure water, 5 $\mu \mathrm{L}$ of $5 \mathrm{X}$ Green Go Taq Flexi Buffer (Promega, USA), 2 $\mu \mathrm{L}$ of $25 \mathrm{mM} \mathrm{MgCl}_{2}$ solution (Promega, USA), $0.5 \mu \mathrm{L}$ of $10 \mathrm{mM}$ deoxynucleotide triphosphate (dNTP) (Promega, USA), $0.5 \mu \mathrm{L}$ of $10 \mathrm{uM} c t x \mathrm{~B}$ forward and reverse primers (IDT, Singapore), $0.5 \mu \mathrm{L}$ of $10 \mathrm{uM} t c p$ I forward and reverse primers (IDT, Singapore), $0.5 \mu \mathrm{L}$ of $10 \mathrm{uM}$ $h l y \mathrm{~A}$ forward and reverse primers (IDT, Singapore), 0.4 $\mu \mathrm{L}$ of $5 \mathrm{U} / \mu \mathrm{L}$ Go Taq DNA polymerase (Promega, USA), and $2 \mu \mathrm{L}$ of DNA template.

The PCR assay was performed with the Veriti 96Well Thermal Cycler (Applied Biosystems, Singapore). The PCR reaction initiated with pre-denaturation at $95^{\circ} \mathrm{C}$ for 5 mins, 35 cycles of denaturation at $95^{\circ} \mathrm{C}(45 \mathrm{~s})$, annealing at $55^{\circ} \mathrm{C}(1 \mathrm{~min})$ and extension at $72^{\circ} \mathrm{C}(1 \mathrm{~min}$ $30 \mathrm{~s}$ ), followed by a final extension at $72^{\circ} \mathrm{C}$ for 5 mins.

PCR products were run through electrophoresis using $1.0 \%$ of an agarose gel, $70 \mathrm{~V}$ for 60 mins. DNAmolecular ladder, $100 \mathrm{bp}$, (Promega Madison, USA) was included for each electrophoresis gel run. The result was visualized using the Fujifilm LAS-3000 Imager (Fujifilm, Japan).

\subsubsection{LAMP assay}

LAMP assay was carried out in a total of $25 \mu \mathrm{L}$ of reagents mixture containing $7.2 \mu \mathrm{L}$ of sterile ultra-pure water, $12.5 \mu \mathrm{L}$ of $2 \mathrm{x}$ Reaction Mix (RM) (Loopamp, Japan), $2 \mu \mathrm{L}$ of $30.77 \mathrm{uM} V$. cholerae Primer Mix (PM)
(Loopamp, Japan), $1 \mu \mathrm{L}$ of Fluorescent Detection Reagent (FD) (Loopamp, Japan), $1 \mu \mathrm{L}$ of Bst DNA polymerase (Loopamp, Japan), and $2 \mu \mathrm{L}$ of DNA template. The reagents mixture was then be heated in a thermal cycler at $63^{\circ} \mathrm{C}$ for 60 mins (predetermined time) and terminated at $80^{\circ} \mathrm{C}$ for 10 mins. Finally, the LAMP products were observed for colour changes. The changed in colour from yellowish orange to green fluorescent indicated the LAMP product was positive, but if the colour remains unchanged, it indicated negative result.

\section{Results and discussion}

\subsection{Prevalence of Vibrio cholerae in Samples}

Vibrio spp. infection has been found to be one of the most common foodborne infections in Asia (Sutherland and Varnam, 2000). The infections are usually initiated by consumption of raw or undercooked seafood (Ottaviani et al., 2009; Baker-Austin, 2015), which may be contaminated by the presence of the pathogen in the marine environment (Sutherland and Varnam, 2000). Poor hygiene practices by food handlers during processing and post-processing of food may cause the pathogens to multiply and re-contaminated the food under favourable conditions which might pose a significant risk of food poisoning. Table 2 and Table 3 summarizes the prevalence of $V$. cholerae in satar and otak-otak obtained throughout this study.

The present study showed $7.96 \%$ of 113 samples fish

Table 2. Number of samples positive for Vibrio cholerae in satar detected using multiplex PCR, LAMP methods and plating.

\begin{tabular}{|c|c|c|c|c|c|c|c|c|}
\hline \multirow{2}{*}{ District } & \multirow{2}{*}{ Stall } & \multirow{2}{*}{$\mathrm{N}$} & \multicolumn{4}{|c|}{ Multiplex PCR } & \multirow{2}{*}{ LAMP } & \multirow{2}{*}{ Plating } \\
\hline & & & $\mathrm{n}$ & $\operatorname{ctx} B$ & tcpI & hlyA & & \\
\hline \multirow{4}{*}{ Besut } & PB (1) & 10 & 0 & 0 & 0 & 0 & 0 & 0 \\
\hline & PB (2) & 5 & 0 & 0 & 0 & 0 & 0 & 0 \\
\hline & PR & 5 & 0 & 0 & 0 & 0 & 0 & 0 \\
\hline & $\mathrm{T}$ & 10 & 0 & 0 & 0 & 0 & 0 & 0 \\
\hline Setiu & $\mathrm{S}$ & 10 & 0 & 0 & 0 & 0 & 0 & 0 \\
\hline \multirow{2}{*}{ Kuala Terengganu } & BR (1) & 16 & 4 & 0 & 4 & 3 & 4 & 0 \\
\hline & $\mathrm{BR}(2)$ & 12 & 4 & 0 & 0 & 4 & 4 & 0 \\
\hline Marang & M & 5 & 0 & 0 & 0 & 0 & 0 & 0 \\
\hline Kemaman & $\mathrm{K}$ & 5 & 0 & 0 & 0 & 0 & 0 & 0 \\
\hline Total: & & 78 & 8 & 0 & 4 & 7 & 8 & 0 \\
\hline
\end{tabular}

Table 3. Number of samples positive for Vibrio cholerae in otak-otak detected using multiplex PCR, LAMP methods, and plating.

\begin{tabular}{|c|c|c|c|c|c|c|c|c|}
\hline \multirow{2}{*}{ District } & \multirow{2}{*}{ Stall } & \multirow{2}{*}{$\mathrm{N}$} & \multicolumn{4}{|c|}{ Multiplex PCR } & \multirow{2}{*}{ LAMP } & \multirow{2}{*}{ Plating } \\
\hline & & & $\mathrm{n}$ & $\operatorname{ctx} B$ & tcpI & hlyA & & \\
\hline \multirow{2}{*}{ Besut } & PB (1) & 10 & 0 & 0 & 0 & 0 & 0 & 0 \\
\hline & PB (2) & 10 & 0 & 0 & 0 & 0 & 0 & 0 \\
\hline Setiu & $\mathrm{S}$ & 5 & 0 & 0 & 0 & 0 & 0 & 0 \\
\hline Kuala Terengganu & BR (1) & 10 & 0 & 0 & 0 & 0 & 0 & 0 \\
\hline Total: & & 35 & 0 & 0 & 0 & 0 & 0 & 0 \\
\hline
\end{tabular}


-based street food products including 78 satar and 35 otak-otak which obtained from different districts in Terengganu were detected for $V$. cholerae. From the data collected, it showed that $V$. cholerae was only present in satar (8 satar), and not otak-otak. This means the prevalence of $V$. cholerae in satar $(11.5 \%)$ was higher than otak-otak (0\%). All the positive samples were purchased in Kuala Terengganu from two different stalls, BR (1) and BR (2).

This study revealed that $V$. cholerae was found in certain fish-based street food products commonly found in Malaysia, even though the detection is low. In accordance to Hong Kong, Food and Environmental Hygiene Department (FEHD) (2005), indigenous microflora in the live seafood might harbor Vibrio spp. at the time of seafood capture or harvest. Meanwhile, previous studies showed positive detection of $V$. cholerae in raw seafood samples such as shrimp, squid, crab, cockles, mussels, mackerel, clam, prawn, and fish (Elhadi et al., 2004; Ottaviani et al., 2009; Mrityunjoy et al., 2013). Differ with raw seafood, the presence of high salt content as one of the ingredients in the seafood products may reduce the growth of $V$. cholerae as it can grow in the salt range of $0.1-4.0 \% \mathrm{NaCl}$, while optimum is $0.5 \% \mathrm{NaCl}$ (Rabbani and Greenough, 1999).

Besides that, $V$. cholerae grow optimally at $37^{\circ} \mathrm{C}$ within the temperature range of $10^{\circ} \mathrm{C}$ to $43^{\circ} \mathrm{C}$ (FEHD, 2005) and they are very sensitive to both heat and radiation, as well as dry condition (ICMSF, 1996), hence, its prevalence in seafood products especially in satar and otak-otak may be lowered as both of these street foods used traditional grilling method in their preparation process. This type of cooking method can accelerate the reduction of moisture content of the foods. However, if the process is not properly controlled, satar and otak-otak may be burnt on the outside but undercooked inside. As such, the contaminated satar and otak-otak will pose a risk of food poisoning due to Vibrios capable of surviving for up to 6 hours (Tang et al., 2017).

Generally, microorganisms need water for their growth. The range of water activity for $V$. cholerae is between $0.940-0.988$, with an optimum water activity of 0.984 (Rabbani and Greenough, 1999). In addition, $V$. cholerae may survive for several days and multiply in food that is alkaline and moist (European Commission, 1998). Heating shellfish for several minutes until the internal temperature of at least $60^{\circ} \mathrm{C}$ is sufficient to kill the pathogenic Vibrios (Anon, 1991). Vibrios were found to be able to grow well in a variety of cooked foods with alkaline pH at $22^{\circ} \mathrm{C}, 30^{\circ} \mathrm{C}$ and $37^{\circ} \mathrm{C}$, such as cooked prawns, hard boiled eggs and cooked mussels (Kolvin and Roberts, 1982).

The prevalence of $V$. cholerae in satar was higher than those found in otak-otak might result from the undercooked thicker and moist satar in certain samples. In contrast, otak-otak is less moist than satar because of its lower in size and thickness. Therefore, otak-otak may be cooked evenly and achieved adequate heat or temperature to eliminate the growth of $V$. cholerae in a shorter time than satar needed.

Besides that, it has been commonly known that water is an important factor in the transmission of cholera which has been implicated with six pandemics. Generally, $V$. cholerae is widely distributed in tropical aquatic environments and shows the highest numbers in temperate water. According to Wong and Desmarchelier (1999), the optimum water temperatures for the isolation of $V$. cholerae are $20-35^{\circ} \mathrm{C}$, and culturable cells may no longer be detectable when the temperature drops below $16^{\circ} \mathrm{C}$.

Both molecular methods employed in this study, namely PCR and LAMP, performed equally well in detecting the presence of Vibrio cholerae in samples collected. Figure 2 shows amplification using multiplex

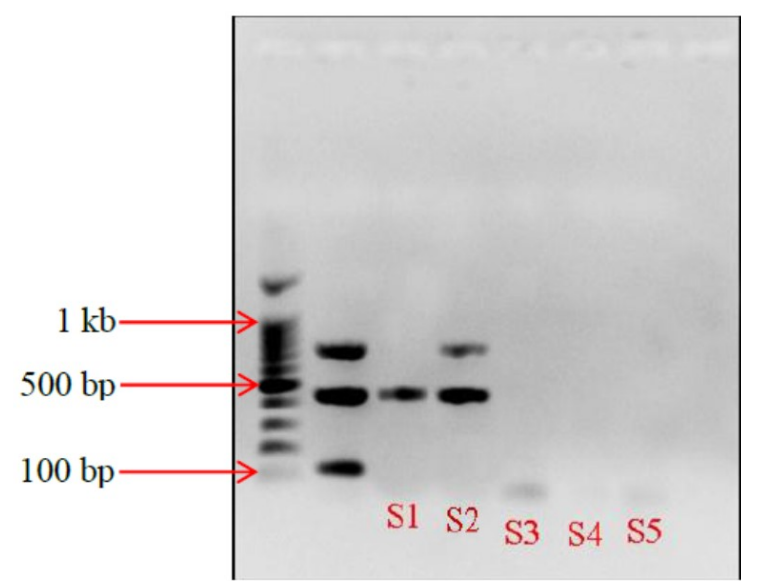

Figure 2. Gel electrophoresis of PCR amplification for $c t x \mathrm{~B}$ (128 bp), tcp I (444 bp) and hlyA (738/727 bp). Lane 1: $100 \mathrm{bp}$ molecular ladder; Lane 2: positive control using DNA from $V$. cholerae clinical; Lane 3: DNA extracted from S1 BR (1); Lane 4: DNA extracted from S2 BR (1); Lane 5: DNA extracted from S3 PB (1); Lane 6: DNA extracted from S4 PB (1); Lane 7: DNA extracted from S5 PB (1); Lane 8: negative control.

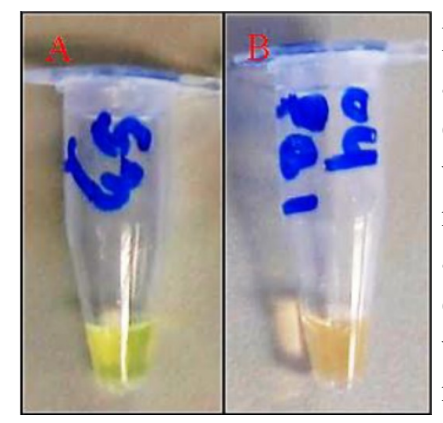

Figure 3. A: LAMP amplification for DNA extracted from S6 BR (1) which showed positive LAMP reaction; B: LAMP amplification for DNA extracted from $\mathrm{O} 4 \mathrm{~PB}$ (1) which showed negative LAMP reaction. 
PCR assay detecting $c t x B$, tcpI and hlyA genes of $V$.cholerae. There was no $V$. cholerae isolate obtained from conventional culture detection method using TCBS agar. This result was in agreement with previous findings that showed that the culture method lacked sensitivity for the detection of low cell numbers compared to molecular method (Harwood et al., 2004). Loop-mediated isothermal amplification (LAMP) was introduced in the year 2000 (Notomi et al., 2000) uses single temperature at $63^{\circ} \mathrm{C}$ and requires an hour to complete the assay. Visual observation of positive and negative reactions was possible from the colour change in the LAMP assay without gel electrophoresis step. These advantages greatly reduce the analysis time of from 4 hours in conventional PCR to 1 hour in LAMP assay. Such method is important for a small and less equipped laboratory setting or during field work. Figure 3 shows the positive and negative reaction of LAMP method.

\section{Conclusion}

Both multiplex PCR and LAMP method performed equally in the detection of $V$. cholerae in satar and otakotak. The prevalence of $V$. cholerae was found to be low in satar and otak-otak sampled in Terengganu. However, proper food handling should be practised at all times to prevent foodborne diseases resulted from undercooked and contaminated products.

\section{Conflict of interest}

The authors declare that there is no conflict of interest in the present study.

\section{Acknowledgement}

The authors would like to thank fund provider International Foundation of Sciences, Sweden (E/52372F), Research Acculturation Collaborative Effort, Ministry of Higher Eduction (RACE/F1/SG4/ UNISZA/4) and in part by Kakenhi Grant-in-Aid for Scientific Research (KAKENHI 24249038). Special thanks to Universiti Sultan Zainal Abidin, Malaysia for providing the facilities. The study will not be successful without these.

\section{References}

Anon. (1991). Cholera outbreak - Peru, Ecuador, and Colombia. Morbidity and Mortality Weekly Report, 40(13), 225-227.

Baker-Austin, C. (2015). Chapter 6 - Antimicrobial Resistance in Vibrio Species. In Chen, C.Y., Yan, X., and Jackson, C.R. (Eds.). Antimicrobial Resistance and Food Safety. Methods and Techniques, p. 105-118. London, UK: Elsevier.
https://doi.org/10.1016/B978-0-12-801214-7.000065

Baumann, P., Furniss, A.L. and Lee J.V. (1984). Genus 1, Vibrio. In Holt, J.G. and Krieg, N.R. (Eds.), Bergey's Manual of Systematic Bacteriology p. 518538. Baltimore, M.D.: Williams and Wilkins.

Colwell, R.R. (1996). Global climate and infectious disease: The cholera paradigm. Science, 274, 20252031. https://doi.org/10.1126/science.274.5295.2025

Elhadi, N., Son, R., Chen, C.H. and Nishibuchi, M. (2004). Prevalence of potentially pathogenic Vibrio species in the seafood marketed in Malaysia. Journal of Food Protocol, 67(7), 1469-1475. https:// doi.org/10.4315/0362-028X-67.7.1469

Etinosa, O.I. and Anthony, I.O. (2008). Emerging Vibrio species: An unending treat to public health in developing countries. Research in Microbiology, 159, 495-506. https://doi.org/10.1016/ j.resmic.2008.07.001

European Commission. (1998). Food Safety: From Farm to Fork. Retrieved on 24 May, 2018 from European Commission: http://ec.europa.eu/food/fs/sc/scf/ out12_en.html

Feldhusen, F. (2000). The role of seafood in bacterial foodborne diseases. Microbes and Infection, 2(13), 1651-1660. https://doi.org/10.1016/S1286-4579(00) 01321-6

Food and Environmental Hygiene Department (FEHD): Queensway, Hong Kong. (2005). Vibrio species in seafood. Retrieved on 25 May, 2018 from Food and Environmental Hygiene Department, Hong Kong: http://www.cfs.gov.hk/english/programme/ programme_rafs/files/vibrios_ra.pdf

Fraga, S.G., Pichel, M., Costagliola, M., Cecilia, M., Jurquiza, V., Peresuti, S., Caffer, M.I., Aulet, O., Hozbor, C., Tracanna, B.C., de Gamundi, A.V., Hernandez, D. and Ramirez, F.C. (2007). Environment and virulence factors of Vibrio cholerae strains isolated in Argentina. Journal of Applied Microbiology, 103(6), 2448-2456. https:// doi.org/10.1111/j.1365-2672.2007.03468.x

Harwood, V.J., Gandhi, J.P. and Wright, A.C. (2004). Methods for isolation and confirmation of Vibrio vulnificus from oysters and environmental sources: a review. Journal of Microbiological Methods, 59(3), 301-316. https://doi.org/10.1016/

j.mimet.2004.08.001

International Commission on Microbiological Specifications for Foods (ICMSF). (1996). Vibrio cholerae. In Microorganisms in Foods 5 Microbiological Specifications of Food Pathogens, p. 414-425. London: Blackie Academic and 
Professional.

Kaper, J.B., Morris Jr, J.G. and Levine, M.M. (1995). Cholera. Clinical Microbiology Reviews, 8(1), 48-86.

Kolvin, J.L. and Roberts, D. (1982). Studies on the growth of Vibrio cholerae biotype classical in foods. Journal of Hygiene, 89, 243-252. https:// doi.org/10.1017/S0022172400070777

Mrityunjoy, A., Kaniz, F., Fahmida, J., Shanzida, J.S., Md. Aftab, U. and Rashed, N. (2013). Prevalence of Vibrio cholerae in different food samples in the city of Dhaka, Bangladesh. International Food Research Journal, 20(2), 1017-1022.

Notomi, T., Okayama, H., Masubuchi, H., Yonekawa, T., Watanabe, K., Amino, N. and Hase, T. (2000). Loop-mediated isothermal amplification of DNA. Nucleic Acids Research, 28(12), E63. https:// doi.org/10.1093/nar/28.12.e63

Oliver, J.D. (2003). Culture media for the isolation and enumeration of pathogenic Vibrio species in foods and environmental samples. In Corry, J.E.L., Curtis, G.D.W. and Baird R.M. (Eds.). Handbook of Culture Media for Food and Water, p. 249-269. London, UK: Elsevier. https://doi.org/10.1016/S0079-6352(03) 80020-6

Ottaviani, D., Leoni, F., Rocchegiani, E., Santarelli, S., Masini, L., Trani, V.D., Canonico, C., Pianetti, A., Tega, L. and Carraturo, A. (2009). Prevalence and virulence properties of non-O1 non-O139 Vibrio cholerae strains from seafood and clinical samples collected in Italy. International Journal of Food Microbiology, 132(1), 47-53. https:// doi.org/10.1016/j.ijfoodmicro.2009.03.014

Rabbani, G.H. and Greenough, W.B. (1999). Food as a vehicle for the transmission of cholera. Journal of Diarrhoeal Disease Research, 17(1), 1-9.

Shrestha, S.D., Malla, S., Adhikari, B.R., Shakya, G., Basnyat, S.R. and Sharma, S. (2010). Antibiotic susceptibility patterns of Vibrio cholerae isolates. Journal Nepal Medicine Association, 49(179), 232236.

Supungul, P., Klinbunga, S., Pichyangkura, R., Hirono, I., Aoki, T. and Tassanakajon, A. (2004). Antimicrobial peptides discovered in the black tiger shrimp Penaeus monodon using the EST approach. Diseases of Aquatic Organisms, 61(1-2), 123-135. https://doi.org/10.3354/dao061123

Sutherland, J. and Varnam, A. (2000). Enterotoxinproducing Staphylococcus, Shigella, Yersinia, Vibrio, Aeromonas and Plesiomonas. In Blackburn, C.W. and McClure, P.J. (Eds.). Foodborne Pathogens, Hazards, Risk Analysis and Control, p. 358-415. Cambridge, UK: Woodhead Publishing
Limited

Suzita, R., Abdulamir, A.S., Fatimah, A.B. and Son, R. (2009). A mini review: cholera outbreak via shellfish. American Journal of Infectious Diseases, 5 (1), 40-47. https://doi.org/10.3844/ajidsp.2009.40.47

Tang, J.Y.H., Mat-Sa'ad, S.H., Banerjee, S.K., Ho, L.H. and Son, R. (2017). Survivability of Vibrio parahaemolyticus in satar and otak-otak, Malaysian fish-based street food. International Food Research Journal, 24(3), 1000-1005.

Tang, J.Y.H., Wan-Rosli, W.F., Abdul-Razak, N.H., Yeo, C.C., Abu Bakar, C.A. and Son, R. (2014). Incidence and antibiogram of Vibrio parahaemolyticus in processed and frozen bivalve mollusks in Kuala Terengganu, Malaysia. International Food Research Journal, 21(3), 19491953.

Weinke, T. Liebold I., Burchard, G.D., Frühwein, N., Grobusch, M.P., Hatz, C., Kollaritsch, H., Nothdurft, H.D., Reisinger, E., Rieke, B., Schönfeld, Ch., Steffen R. and Stich, A. (2008). Prophylactic immunization against traveller's diarrhoea caused by enterotoxin forming strains of Escherichia coli and against cholera, travel medicine and infectious disease. Travel Medical Infectious Disease, 6(6), 362 -336. https://doi.org/10.3844/ajidsp.2009.40.47

Wong, F.Y.K. and Desmarchelier, P.M. (1999). Vibrio cholera. In Robinson, R.K., Batt, C.A. and Patel, P.D. (Eds.). Encyclopedia of Food Microbiology, p. 2242-2257. Australia: Academic Press,. https:// doi.org/10.1006/rwfm.1999.1655 